\title{
High-level expression of protein tyrosine phosphatase non-receptor 12 is a strong and independent predictor of poor prognosis in prostate cancer
}

Sören A. Weidemann ${ }^{1 \dagger}$, Charlotte Sauer ${ }^{1 \dagger}$, Andreas M. Luebke ${ }^{1}$, Christina Möller-Koop ${ }^{1}$, Stefan Steurer ${ }^{1}$, Claudia Hube-Magg ${ }^{1}$, Franziska Büscheck', Doris Höflmayer ${ }^{1}$, Maria Christina Tsourlakis' ${ }^{1}$, Till S. Clauditz' Ronald Simon ${ }^{1 *}$ D, Guido Sauter ${ }^{1}$, Cosima Göbel ${ }^{1}$, Patrick Lebok ${ }^{1}$, David Dum', Christoph Fraune ${ }^{1}$, Simon Kind ${ }^{1}$, Sarah Minner ${ }^{1}$, Jakob Izbicki ${ }^{2}$, Thorsten Schlomm³ ${ }^{3}$, Hartwig Huland ${ }^{4}$, Hans Heinzer ${ }^{4}$, Eike Burandt ${ }^{1}$, Alexander Haese ${ }^{4}$, Markus Graefen ${ }^{4}$ and Asmus Heumann ${ }^{2}$

\begin{abstract}
Background: Protein tyrosine phosphatase non-receptor 12 (PTPN12) is ubiquitously tyrosine phosphatase with tumor suppressive properties.

Methods: PTPN12 expression was analyzed by immunohistochemistry on a tissue microarray with 13,660 clinical prostate cancer specimens.

Results: PTPN12 staining was typically absent or weak in normal prostatic epithelium but seen in the majority of cancers, where staining was considered weak in $26.5 \%$, moderate in 39.9\%, and strong in $4.7 \%$. High PTPN12 staining was associated with high pT category, high classical and quantitative Gleason grade, lymph node metastasis, positive surgical margin, high Ki67 labeling index and early prostate specific antigen recurrence ( $p<$ 0.0001 each). PTPN12 staining was seen in $86.4 \%$ of TMPRSS2:ERG fusion positive but in only $58.4 \%$ of ERG negative cancers. Subset analyses discovered that all associations with unfavorable phenotype and prognosis were markedly stronger in ERG positive than in ERG negative cancers but still retained in the latter group. Multivariate analyses revealed an independent prognostic impact of high PTPN12 expression in all cancers and in the ERG negative subgroup and to a lesser extent also in ERG positive cancers. Comparison with 12 previously analyzed chromosomal deletions revealed that high PTPN12 expression was significantly associated with 10 of 12 deletions in ERG negative and with 7 of 12 deletions in ERG positive cancers ( $p<0.05$ each) indicating that PTPN12 overexpression parallels increased genomic instability in prostate cancer.
\end{abstract}

Conclusions: These data identify PTPN12 as an independent prognostic marker in prostate cancer. PTPN12 analysis, either alone or in combination with other biomarkers might be of clinical utility in assessing prostate cancer aggressiveness.

Keywords: PTPN12, Prostate cancer, Prognosis, Immunohistochemistry

\footnotetext{
* Correspondence: r.simon@uke.de

†'

${ }^{1}$ Institute of Pathology, University Medical Center Hamburg-Eppendorf,

Martinistrasse 52, 20246 Hamburg, Germany

Full list of author information is available at the end of the article
}

(c) The Author(s). 2019 Open Access This article is distributed under the terms of the Creative Commons Attribution 4.0 International License (http://creativecommons.org/licenses/by/4.0/), which permits unrestricted use, distribution, and reproduction in any medium, provided you give appropriate credit to the original author(s) and the source, provide a link to the Creative Commons license, and indicate if changes were made. The Creative Commons Public Domain Dedication waiver (http://creativecommons.org/publicdomain/zero/1.0/) applies to the data made available in this article, unless otherwise stated. 


\section{Background}

With more than 1.3 million estimated new cases worldwide in 2018, prostate cancer is the most common cancer in males in over one-half of the countries of the world [1]. The clinical course is highly variable. In elderly and symptom-free patients watchful waiting and active surveillance are alternatives to surgical therapy in localized disease [2]. The currently available criteria used for the distinction between high risk and low risk patients, such as Gleason grade, clinical stage and prostate specific antigen (PSA) level, are statistically powerful but not sufficient to enable optimal treatment decisions for every patient. To more reliably prevent unnecessary treatments better prognostic markers are needed.

Protein tyrosine phosphatase non-receptor 12 (PTPN12) is a member of the protein tyrosine phosphatases family, which is ubiquitously expressed [3, 4]. It dephosphorylates cellular tyrosine kinases, such as HER2 [5] and functions as a tumor suppressive key regulator of signaling pathways involved in cell-extracellular matrix crosstalk, cellular responses to mechanical stress and cell adhesion $[6,7]$. The oncogene c-ABL is an important target of PTPN12 driven dephosphorylation resulting in its down regulation [8, 9]. A number of studies have reported that decreased expression of PTPN12 as determined by immunohistochemistry was found to be significantly associated with advanced tumor stage in hepatocellular [10,11], renal cell [12], and urinary bladder [13] as well as in squamous cell carcinoma of the oral cavity, esophagus and nasopharynx [14-17]. High PTPN12 expression was described to be linked with favorable survival duration in non-small cell lung carcinoma patients [18] and with response to neoadjuvant chemotherapy in triple negative breast cancer [19].

Evidence suggests that PTPN12 expression might also be relevant for prostate cancer. Using PC-3 cell lines Sahu et al. showed a role of PTPN12 in regulating migration of prostate cells [20]. For this purpose, a preexisting prostate cancer tissue microarray (TMA) consisting of more than 13,000 prostate cancers with clinical follow-up information and attached molecular data was examined for PTPN12 expression levels.

\section{Methods \\ Patients}

The 13,660 patients had radical prostatectomy between 1992 and 2015 (Department of Urology and the Martini Clinic at the University Medical Center HamburgEppendorf). Classical Gleason categories and "quantitative" Gleason grading was performed as described [21]. In brief, for quantitative Gleason grading the percentage of Gleason 4 patterns was recorded to categorize the Gleason grades in 12 groups. Follow-up was available for 12,208 patients with a median follow-up of 49 months (Table 1). PSA recurrence was defined as the time point
Table 1 Pathological and clinical data of the arrayed prostate cancers

\begin{tabular}{|c|c|c|}
\hline & \multicolumn{2}{|c|}{ No. of patients (\%) } \\
\hline & $\begin{array}{l}\text { Study cohort } \\
\text { on TMA }\end{array}$ & $\begin{array}{l}\text { Biochemical relapse } \\
\text { among categories }\end{array}$ \\
\hline \multicolumn{3}{|l|}{ Follow-up } \\
\hline$n$ & 12,208 & $2759(22.6 \%)$ \\
\hline Mean / median (month) & $59 / 49$ & - \\
\hline \multicolumn{3}{|l|}{ Age (y) } \\
\hline$\leq 50$ & 310 & $54(17.4 \%)$ \\
\hline $51-59$ & 3278 & $656(20.0 \%)$ \\
\hline $60-69$ & 7539 & $1693(22.5 \%)$ \\
\hline$\geq 70$ & 2251 & $501(22.3 \%)$ \\
\hline \multicolumn{3}{|l|}{ Pretreatment PSA (ng/ml) } \\
\hline$<4$ & 1659 & $242(14.6 \%)$ \\
\hline $4-10$ & 7942 & $1355(17.1 \%)$ \\
\hline $10-20$ & 2807 & $737(26.3 \%)$ \\
\hline$>20$ & 940 & $397(42.2 \%)$ \\
\hline \multicolumn{3}{|l|}{ pT stage (AJCC 2002) } \\
\hline pT2 & 8646 & 1095 (12.7\%) \\
\hline рT3а & 2904 & $817(28.1 \%)$ \\
\hline pT3b & 1765 & $796(45.1 \%)$ \\
\hline pT4 & 68 & $51(75 \%)$ \\
\hline \multicolumn{3}{|l|}{ Gleason grade } \\
\hline$\leq 3+3$ & 2638 & $264(10.0 \%)$ \\
\hline $3+4$ & 7172 & $1436(20.0 \%)$ \\
\hline $3+4$ Tert. 5 & 645 & $165(25.6 \%)$ \\
\hline $4+3$ & 1224 & $683(55.8 \%)$ \\
\hline $4+3$ Tert. 5 & 987 & 487 (49.3\%) \\
\hline$\geq 4+4$ & 756 & $531(70.2 \%)$ \\
\hline \multicolumn{3}{|l|}{ pN stage } \\
\hline pNO & 7899 & $1821(23.1 \%)$ \\
\hline $\mathrm{pN}+$ & 855 & $546(63.9 \%)$ \\
\hline \multicolumn{3}{|l|}{ Surgical margin } \\
\hline Negative & 10,768 & $1833(17.0 \%)$ \\
\hline Positive & 2613 & $1059(40.5 \%)$ \\
\hline
\end{tabular}

Abbreviation: AJCC, American Joint Committee on Cancer

${ }^{a}$ Numbers do not always add up to 13,660 in the different categories because of cases with missing data

when postoperative PSA level was $\geq 0.2 \mathrm{ng} / \mathrm{ml}$. The TMA was produced with a single $0.6 \mathrm{~mm}$ core taken from a tumor containing tissue block for each patient [22]. The attached molecular database included data on Ki67 labeling index (Ki67LI) [23], HER2 immunostaining [24], ERG expression and ERG rearrangement analysis by fluorescence in situ hybridization (FISH) $[25,26]$, as well as deletion status of 5q21 (CHD1) [27], 6q15 (MAP3K7) [28], 10q23 (PTEN) [29], 3p13 (FOXP1) [30], 13q14 
[31], 18q21 [32], 8p21 [33], 12p13 [34], 12q24 [35], $16 \mathrm{q} 24$ [36] and 17p13 [37]. Furthermore, data from deletions of 5q13 (5441 tumors, unpublished) were available.

\section{Immunohistochemistry (IHC)}

Tissue microarray sections were stained in a single experiment. Slides were dewaxed and heated for $5 \mathrm{~min}$ at $121^{\circ} \mathrm{C}$ in $\mathrm{pH} 9.0$ antigen retrieval buffer. Primary antibody HPA007097 specific for PTPN12 (rabbit polyclonal antibody, dilution 1:450; Sigma-Aldrich, St. Louis, Missouri, USA) was applied at $37^{\circ} \mathrm{C}$ for $60 \mathrm{~min}$. This antibody was comprehensively validated externally (https://www.protei natlas.org/ENSG00000127947-PTPN12/antibody\#ICC) [38, 39]. Bound antibody was visualized with the EnVision Kit (Dako, Glostrup, Denmark). PTPN12 typically shows cytoplasmic staining of all tumor cells (100\%) of a positive tissue spot with equal staining intensity. Thus, only staining intensity was recorded in a semi quantitative 4-step scale. 'Negative' was assigned if no detectable staining was present. 'Strong' was assigned to all tumors showing intense, dark brown staining. 'Weak' or 'moderate' was assigned to cancer showing staining intensities in between; e.g. as shown in Fig. 1. To rule out interobserver variability scoring was based on a single observer.

\section{Statistics}

Contingency tables and the $\mathrm{chi}^{2}$-test were utilized to examine associations between molecular and histopathological tumor parameters. Kaplan-Meier curves were compared by the log-rank test to detect significant differences between groups. Cox proportional hazards regression analysis was performed to test for statistical independence between pathological, molecular and clinical variables. All calculations were performed with JMP 12 (SAS Institute Inc., NC, USA).

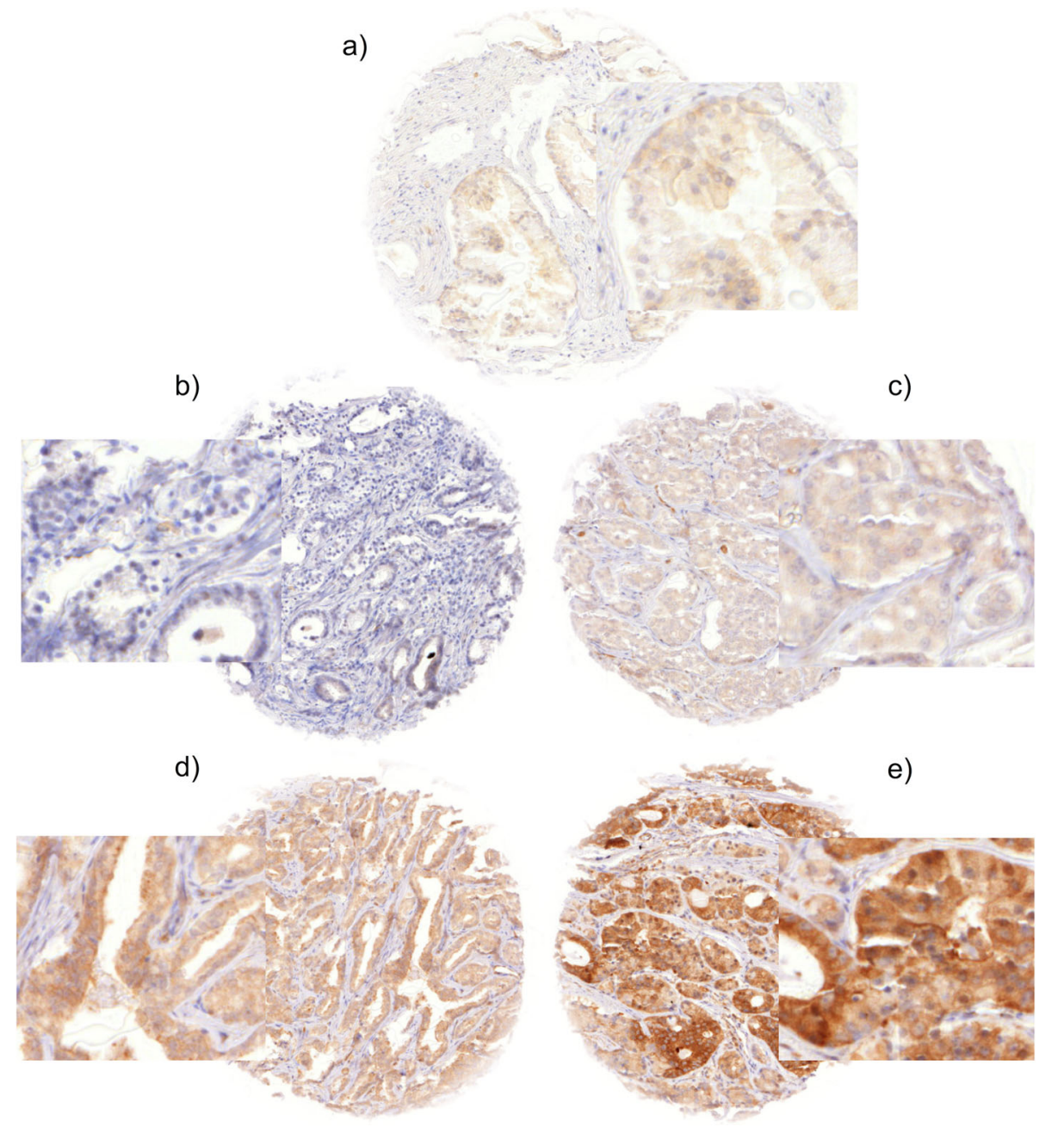

Fig. 1 Representative images of PTPN12 staining in normal (a) and cancerous glands (b-e) with negative (b), weak (c), moderate (d) and strong (e) staining. Spot size is $600 \mu \mathrm{m}$ at $100 / 400 x$ magnification 


\section{Results}

\section{Technical aspects}

A total of 10,317 (76\%) of the 13,660 arrayed tumor samples displayed interpretable PTPN12 staining. Noninformative cases (24\%) were caused by lack of tissue at certain TMA spots or absence of unequivocal cancer cells.

\section{PTPN12 protein expression in normal and cancerous} prostate tissues

In normal prostate epithelial cells, PTPN12 was negative or displayed a weak cytoplasmic immunostaining while basal cells frequently had a moderate positivity (Fig. 1). PTPN12 immunostaining was often more intense in cancers. It was considered negative in $28.9 \%$, weak in $26.5 \%$, moderate in $39.9 \%$, and strong in $4.7 \%$ of cancers (Table 2). High level PTPN12 staining was associated with advanced pT category, high conventional and quantitative Gleason grade, and positive surgical margin status and to a higher likelihood for PSA recurrence $(p<0.0001$ each $)$.

It is of note that the prognostic impact of high PTPN12 staining (Fig. 2a) was also retained in PTEN deleted cancers (Fig. 2e) and in cancers with a Gleason $3+$ 4 (Fig. 2g) or Gleason $\geq 4+3$ (Fig. 2h). It disappeared in most of the quantitative Gleason categories (Additional file 1: Figure S1 b-g) and remained in the category with the highest percentage of Gleason 4 patterns (Additional file 1: Figure $\mathrm{S} 1 \mathrm{~h}$ ).

\section{PTPN12 and TMPRSS2:ERG fusion status}

ERG fusion status by FISH and by IHC was available from 5515 and 8134 tumors respectively (Fig. 3). Concordant results regarding the ERG status using IHC and FISH was obtained in $95.4 \%$ of cases. PTPN12 immunostaining was more prevalent in ERG fusion positive than in ERG wild type cancers. PTPN12 immunostaining was seen in $86.4 \%$ of ERG IHC positive and in only $58.4 \%$ of ERG IHC negative cancers $(p<0.0001)$. Because of these differences, all analyses comparing PTPN12 expression and tumor phenotype or prognosis were also performed in subgroups of ERG positive and negative cancers. This revealed a tighter relationship of high PTPN12 staining levels with unfavorable tumor features in ERG negative than in ERG positive cancers (Fig. 2b and c; Additional file 1: Tables S1 and S2). This was particularly evident for the relationship with PSA recurrence, which was striking in ERG negative $(p<0.0001$, Fig. $2 \mathrm{~b})$ but much less strong in ERG positive cancers ( $p=0.0055$, Fig. $2 c$ ).

\section{PTPN12 and chromosomal deletions}

For all analyzed chromosomal regions, PTPN12 immunostaining was always stronger and more frequent in cases of deletion (Fig. 4a). This was particularly evident
Table 2 PTPN12 staining results of the primary tumor and prostate cancer phenotype in all cancers

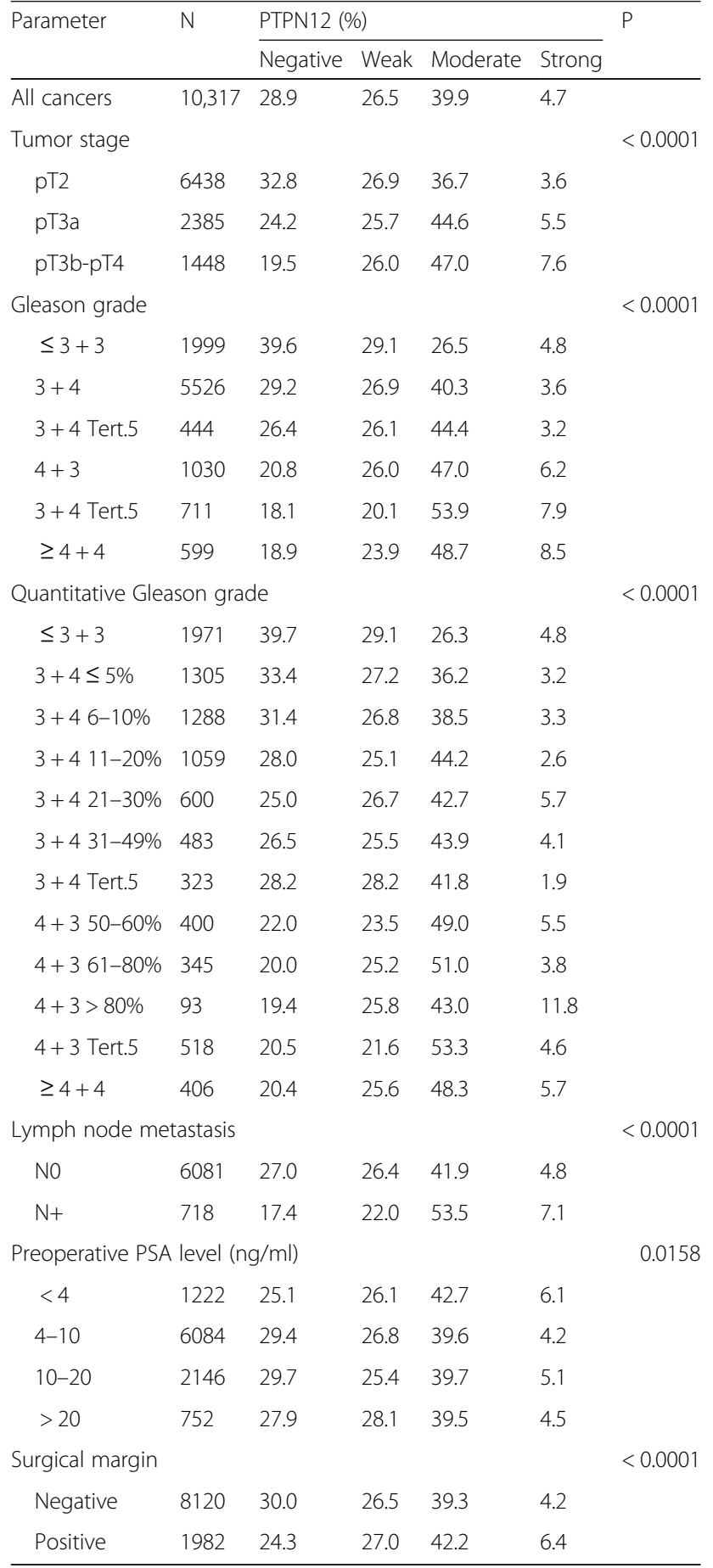

in the subgroup of ERG negative cancers where this difference was statistically significant for 9 of 12 deletions $(p<0.0005$ each, Fig. $4 \mathrm{~b})$. In ERG positive cancers, a statistically significant difference was still seen for 7 of 12 analyzed deletions ( $p<0.05$ each, Fig. 4c). 
a)
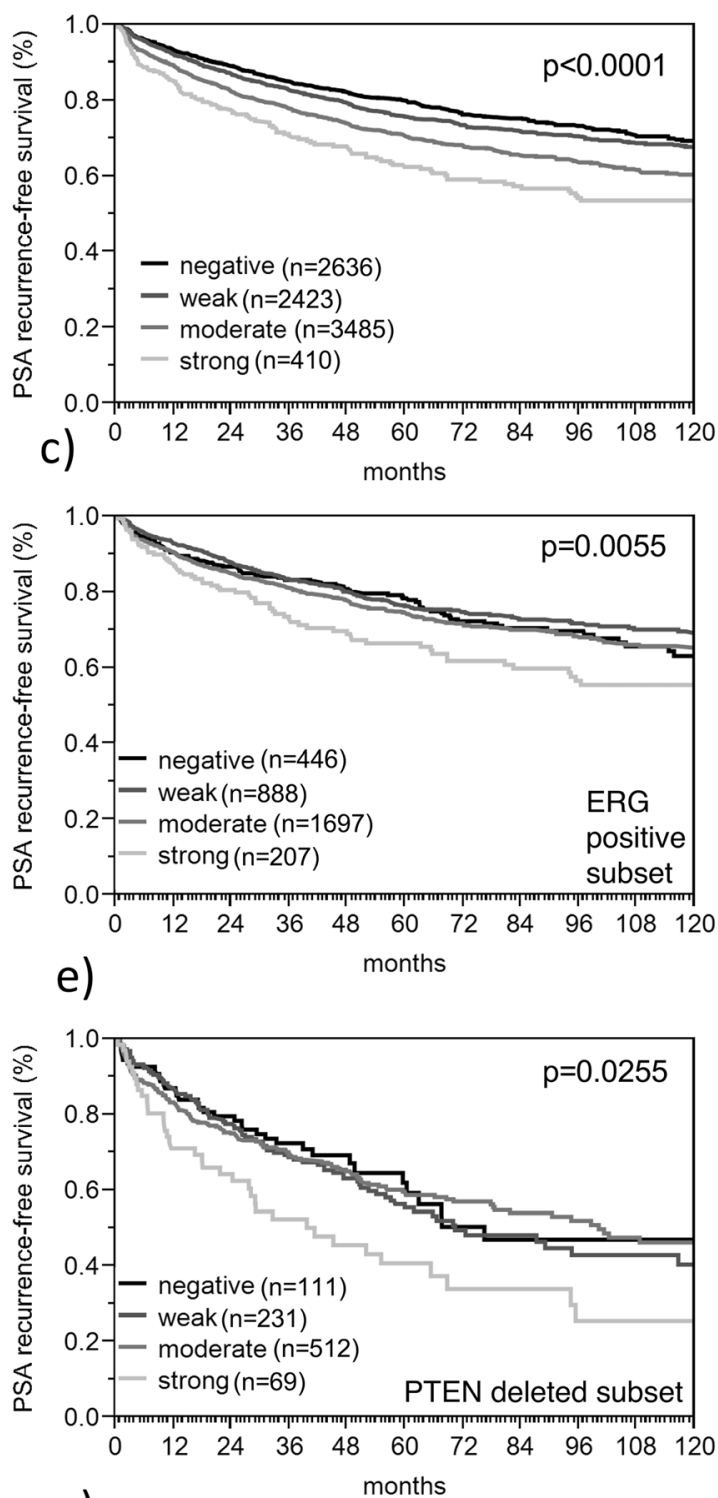

g)

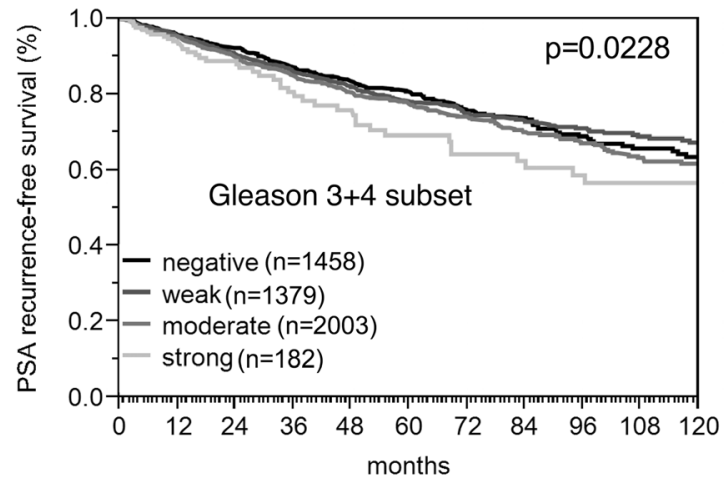

b)
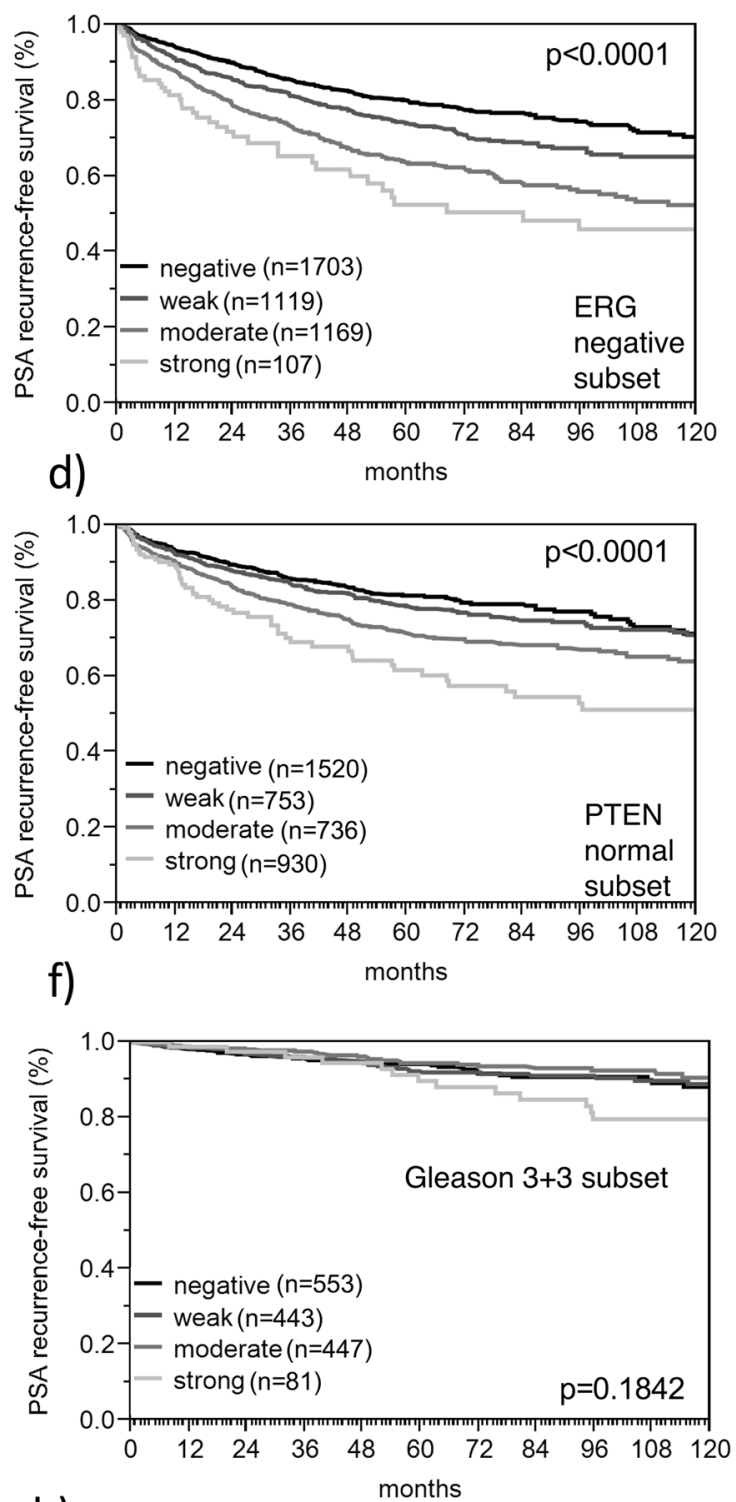

h)

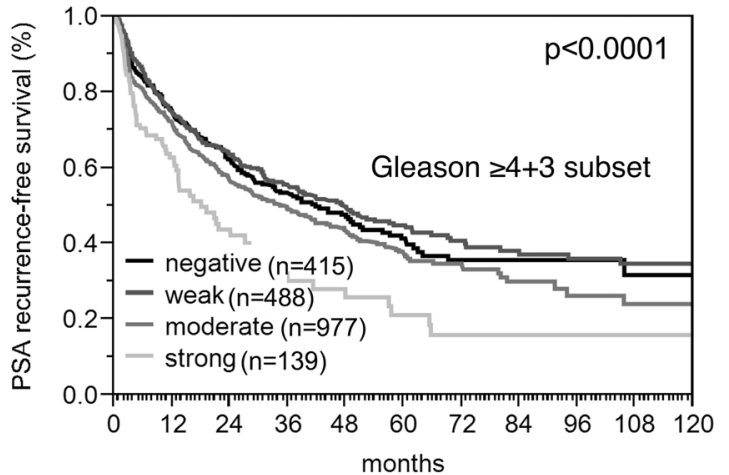

Fig. 2 Association between PTPN12 expression and biochemical recurrence in (a) all cancers, (b) ERG-fusion negative cancers, (c) ERG-fusion positive cancers, (d) PTEN normal cancers, (e) PTEN deleted cancers, (f) Gleason grade 3+3, (g) Gleason grade $3+4$ and (h) Gleason grade $\geq 4+3$ 


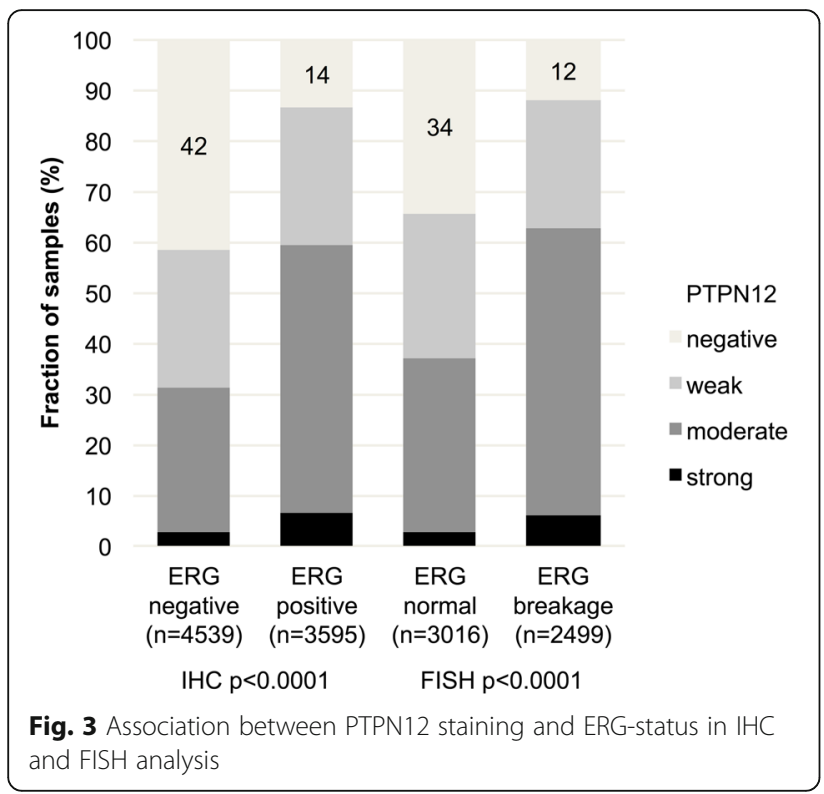

\section{PTPN12, tumor cell proliferation and HER2} immunostaining

High levels of PTPN12 staining were linked to increased cell proliferation as determined by the Ki67-labeling index (Ki67LI). The average Ki67LI increased from 1.82 in PTPN12 negative cancers to 3.61 in cancers with strong PTPN12 staining (Table 3). This association was independent from Gleason score as it held true in all subgroups with high significance $(p<0.0001$ each) except for Gleason score $\geq 4+3(p<0.0047)$.

PTPN12 staining was significantly associated with the expression of HER2 protein (Fig. 5). Negative PTPN12 staining was seen in $32 \%$ of HER2 negative cancers and in $17 \%$ of HER2 positive cancers. The same effect was seen in both ERG subsets.

\section{Multivariate analysis}

Four different models were analyzed (Additional file 1: Table S3): Scenario 1 included the postoperatively available parameters $\mathrm{pT}, \mathrm{pN}$, surgical margin status, preoperative PSA value and prostatectomy Gleason grade. Scenario 2 excluded $\mathrm{pN}$, because the lymph node dissection is not standardized and may introduce a bias towards high-grade cancers. Scenario 3 was a mix of pre- and postoperative parameters (PTPN12 staining, preoperative serum PSA, clinical tumor stage (cT) and the prostatectomy Gleason grade). Since it is well documented that sampling differences lead to up-grading of the postoperative Gleason grades in 36\% of cases [40], this parameter was replaced by the original preoperative biopsy Gleason grade in Scenario 4. These analyses identified PTPN12 as an independent prognostic feature in all 4 scenarios, if the entire cohort or the subgroup of ERG negative cancers was considered $(p<0.0005$ each). Independent prognostic impact, although weaker, was also seen in the ERG positive cancer subset $(p<0.005$ each). The hazard ratio for PSA recurrence after radical prostatectomy for strong versus negative PTPN12 expression was in the univariate model a weak 1.85 for all cancers and a moderate 2.50 in the ERG negative subset as compared with 6.01 for the Gleason grade at biopsy (Table 4).

\section{Discussion}

These data identify high PTPN12 expression as an independent predictor of poor prognosis in prostate cancer.

That PTPN12 immunostaining increased from normal to cancerous epithelial cells in combination with the marked further increase of PTPN12 expression with advanced tumor stage and high Gleason grade, demonstrates that elevated PTPN12 expression parallels tumor development and progression in a fraction of prostate cancers. The striking prognostic role of high PTPN12 expression being independent of all established prognostic features available before and after prostatectomy in our study on 13,660 cancers was not expected. Both functional data from prostate cancer cell lines [20] and earlier reports on PTPN12 down regulation in other cancer types [10-19] suggest a tumor suppressor function of PTPN12. However, that tumor suppressor genes are overexpressed in cancer cells is not uncommon. For example, the tumor suppressor p16 is markedly up regulated in cells infected by human papilloma virus in an attempt to compensate for disrupted p53 and rb pathways $[41,42]$. P16 expression is so massive in affected cells, that p16 expression analysis can be used in HPV associated neoplasia in routine diagnostic [43, 44]. Moreover, it is well possible that the causes and consequences of PTPN12 overexpression differ between different cancer types. Some studies analyzing the prognostic value of PTPN12 in small cohorts of up to 250 patients report a positive correlation of increased PTPN12 expression and outcome in non small cell lung cancer [18], breast cancer [45] and squamous cell carcinoma [14], whereas Zhangyuan et al. found a contrary result in their study in at least one subgroup of non-hepatitis B-positive patients with hepatocellular carcinoma [11]. At present, there is no mechanistic explanation for these findings. However, similar observations have been reported from the tumor suppressor checkpoint kinase 2 (CHK2), a protein interacting with p53 and BRCA1. Both reduced and increased CHK2 expression has been described in different tumor types to be associated with poor patient prognosis [46-48]. The largest study investigating the prognostic role of CHK2 expression on more than 1000 well characterized breast cancers failed to show a prognostic impact of CHK2 expression in all cancers but revealed associations of high CHK2 expression with poor patient outcome in $\mathrm{p} 53$ positive and ER negative cancers 


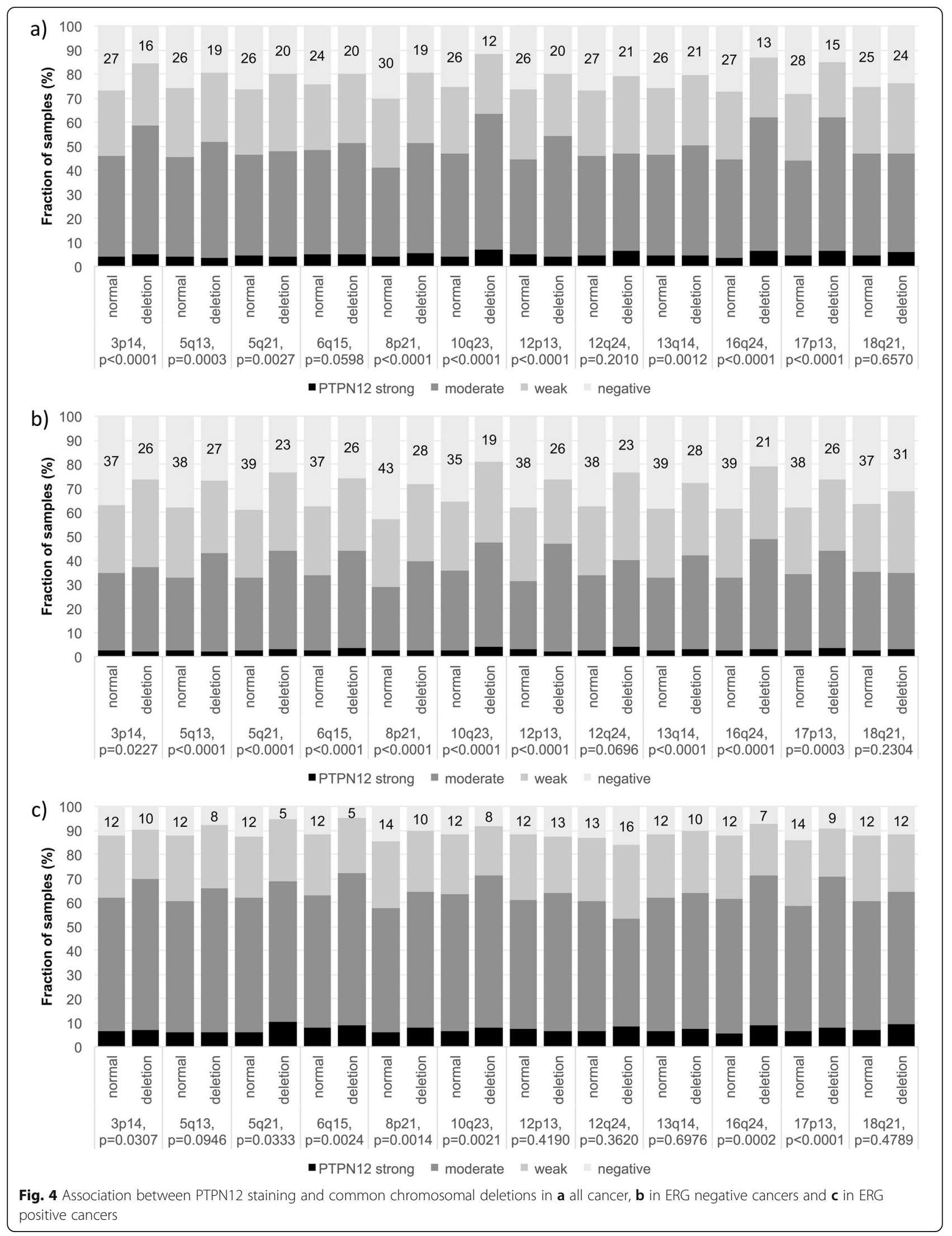


Table 3 Association between PTPN12 expression and Ki67labeling index

\begin{tabular}{llll}
\hline Gleason $(p$-value $)$ & PTPN21 & $N$ & $\begin{array}{l}\text { Ki67 LI } \\
(\text { mean } \pm \text { SEM })\end{array}$ \\
\hline All $(p<0.0001)$ & Negative & 1673 & $1.82 \pm 0.06$ \\
& Weak & 1518 & $2.79 \pm 0.07$ \\
& Moderate & 2103 & $3.36 \pm 0.06$ \\
& Strong & 198 & $3.61 \pm 0.18$ \\
$\leq 3+3(p<0.0001)$ & Negative & 492 & $1.50 \pm 0.09$ \\
& Weak & 362 & $1.98 \pm 0.11$ \\
& Moderate & 332 & $2.39 \pm 0.11$ \\
& Strong & 49 & $2.50 \pm 0.29$ \\
$3+4 p<0.0001$ & Negative & 926 & $1.59 \pm 0.07$ \\
& Weak & 863 & $2.58 \pm 0.08$ \\
& Moderate & 1301 & $3.10 \pm 0.06$ \\
& Strong & 96 & $2.67 \pm 0.23$ \\
& Negative & 189 & $1.8676 \pm 0.26$ \\
& Weak & 223 & $2.9945 \pm 0.24$ \\
& Moderate & 350 & $3.7877 \pm 0.19$ \\
& Strong & 38 & $3.4073 \pm 0.57$ \\
& Negative & 54 & $1.5949 \pm 1.5949$ \\
& Weak & 65 & $3.8142 \pm 3.8142$ \\
& Moderate & 107 & $4.1036 \pm 4.1036$ \\
& Strong & 14 & $4.3912 \pm 4.3912$ \\
\hline 0.0001$)$ & & &
\end{tabular}

Table 4 Cox proportional hazards for PSA recurrence-free survival after prostatectomy of established preoperative prognostic parameter and PTPN12 expression

\begin{tabular}{|c|c|c|}
\hline Variable & Univariable analysis & Multivariable analysis \\
\hline \multicolumn{3}{|l|}{ Gleason grade biopsy } \\
\hline$\geq 4+4$ vs. $\leq 3+3$ & $6.01(5.41-6.66) * * *$ & $4.21(3.71-4.79) * * *$ \\
\hline \multicolumn{3}{|c|}{ Preoperative PSA-level $(n g / \mu l)$} \\
\hline$>20$ vs. $<4$ & $5.12(4.46-5.89) * * *$ & $3.14(2.61-3.80) * * *$ \\
\hline \multicolumn{3}{|l|}{ cT-stage } \\
\hline T2c vs. T1c & $3.95(3.24-4.76) * * *$ & $2.08(1.66-2.58) * * *$ \\
\hline \multicolumn{3}{|l|}{ PTPN12 expression } \\
\hline Strong vs. negative & $1.85(1.53-2.23) * * *$ & $1.71(1.40-2.07) * * *$ \\
\hline ERG negative subset & $2.50(1.82-3.35) * * *$ & $2.28(1.65-3.09) * * *$ \\
\hline ERG positive subset & $1.51(1.23-2.02) *$ & $1.37(1.01-1.85) *$ \\
\hline
\end{tabular}

Confidence interval (95\%) in brackets; asterisk indicate significance level: * $p \leq$ $0.05,{ }^{* *} p \leq 0.001,{ }^{* * *} p \leq 0.0001$; ERG ETS-related gene

while low CHK2 expression was linked to poor prognosis in ER positive cancers [49].

The TMA used in this study had earlier been utilized for dozens of studies evaluating the clinical relevance of molecular features in prostate cancer [50]. This led to an accumulation of relevant molecular information for our patient cohort that can potentially be utilized to hypothesize on the possible functional role of new genes of interest. For the purpose of this study, we compared PTPN12 expression with TMPRSS2:ERG fusion because this is the most common molecular alteration in prostate cancer [51], 12 different chromosomal deletions representing the next most

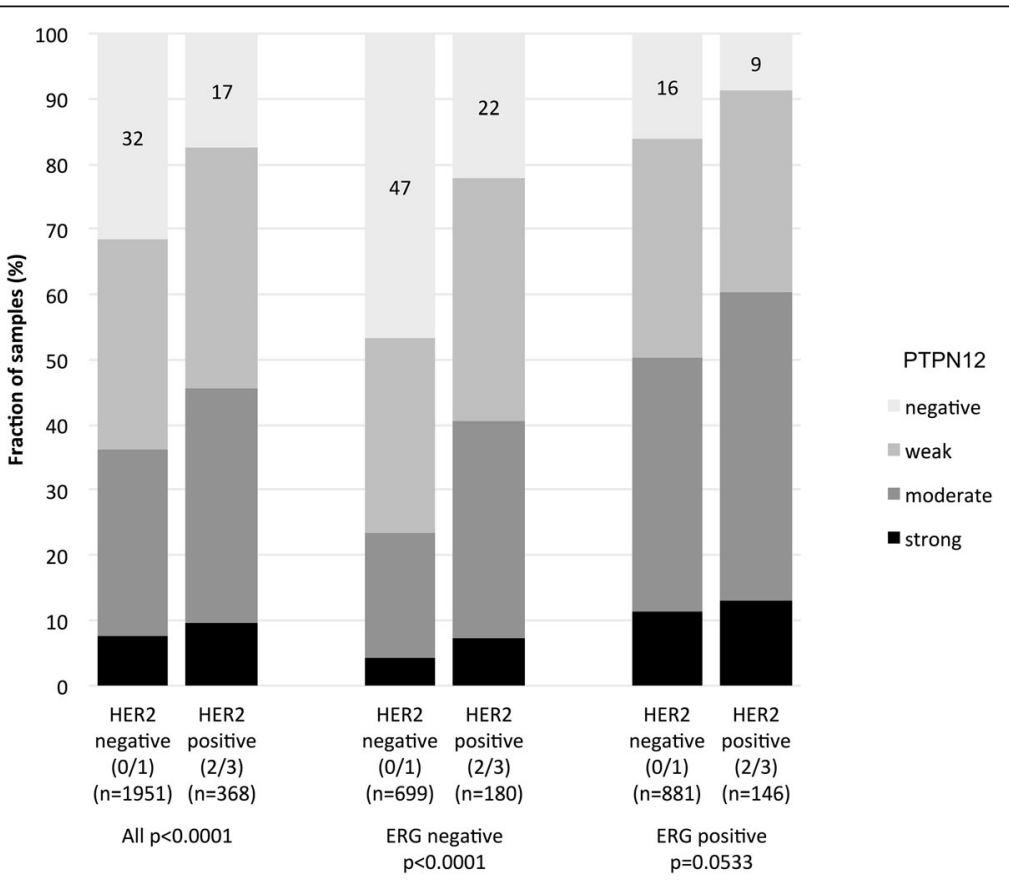

Fig. 5 PTPN12 staining and HER2 expression in all cancers, the ERG negative, and the ERG positive subset 
common genomic alterations in prostate cancer [52], the Ki67 labeling index because of its pivotal role in cancer aggressiveness [53], and immunohistochemical HER2 expression because of the earlier well described interaction with PTPN12 [3, 54]. The significant association of PTPN12 and HER2 expression seen in our patients therefore fits well. TMPRSS2:ERG fusions occur in about $50 \%$ of prostate cancers and result in a permanent expression of the transcription factor ERG. ERG activation by itself lacks prognostic relevance [25] but modulates the expression of more than 1600 genes in affected cells [55]. Our data identify PTPN12 protein as another protein whose expression was increased in ERG positive compared to ERG negative cancers.

That the prognostic role of PTPN12 was more striking in ERG negative and somewhat less prominent in ERG positive cancers fits with the observation, that many molecular features that show different prevalence in ERG positive and ERG negative cancers have a different impact on patient prognosis in these subgroups. For example, the prognostic impact of SOX9 [56], SENP1 [57] and mTOR [58] was limited to ERG positive cancers while FOXA1 [59], MTCO2 [60] and FOXP2 [61] were only prognostic in ERG negative cancers. It is well conceivable that differences in the cellular microenvironment with more than 1600 dysregulated genes in ERG activated cancers impact the biological effect of molecular features such as PTPN12. Dependency of the prognostic impact of biomarkers on other specific molecular tumor features is likely to constitute a significant challenge for the development of prognostic prostate cancer tests.

Most chromosomal deletions are linked to either positive or negative ERG status [28-30, 62]. Molecular features that are also linked to the ERG status, such as PTPN12, are thus expected to show statistically significant associations with ERG dependent deletions. That a separate analysis of subgroups identified significant relationship between high PTPN12 expression and 10 of 12 deletions in ERG negative and of 7 of 12 deletions in ERG positive cancers shows, however, that elevated PTPN12 levels preferentially occur under conditions linked to genomic instability in prostate cancers. That none of the deletions examined in this study was more prominently linked to PTPN12 expression argues against a relevant functional relationship of PTPN12 with genes impacted by these deletions. It seems more likely that the PTPN12 up regulation results from a general response to genetic instability. One of PTPN12s substrates, WASP [63], mediates homology-direct repair together with Arp2/3 in DNA double-strand breaks [64] and could therefore be a conceivable link to PTPN12 overexpression. Also Tang et al. were able to demonstrate that suppression of FAK1, also a target of PTPN12- dephosphorylation [65], leads to activation of DNA repair in lung cancer [66].

Besides the two mentioned, 16 more substrates of PTPN12 are currently known including HER2, PYK2, PSTPIP, p130CAS/BCAR1, paxillin, Shc, catenin, c-Abl, ArgBP2, CAK $\beta$ and members of the Rho proteins [3, 9, 63, 65, 67-74]. Several of these genes play a particular role in the growth controlling EGFR-pathway, which fits well to the markedly elevated Ki67 LI in cancers with high PTPN12 expression. Especially FAK1 is of particular interest in this context. For example, in colonic carcinoma, Fonar and Frank were able to show that FAK is in connection with the Wnt signaling pathway at several sites [75]. In particular, cell cycle control is regulated by transcriptional control of cyclin D1 via FAK. In turn, the Wnt signaling pathway is known to be massively up regulated in ERG translocated prostate carcinomas [76]. This fits with our observations suggesting that this pathway is strongly driven in ERG positive tumors.

This study suggests that PTPN12 expression may represent a useful prognostic biomarker in prostate cancer. This is not only illustrated by the statistical independence of all established prognostic parameters, even if parameters are included that are - such as $\mathrm{pT}$ and $\mathrm{pN}$ unavailable at the time, when therapeutic decisions are taken. Moreover, PTPN12 retained prognostic impact in molecularly defined high risk groups such as in PTEN deleted cancers and in some morphologically defined high-risk groups such as in Gleason $3+4$ cancers. That PTPN12 expression analysis was not better than Gleason grading does not compromise the potential for PTPN12 expression analysis, however. Although Gleason grading is a very powerful statistical parameter, it suffers from notorious interobserver heterogeneity, which is in the range of $40 \%[77,78]$. Accordingly, there is not only a need for better predictors of PCA aggressiveness than the established ones but also for more reproducible ones. Molecular analysis may, thus, help to improve standardization of prognosis assessment in the future.

\section{Conclusions}

This study identifies PTPN12 expression measurement as a valuable prognostic marker in prostate cancer. PTPN12 analysis, either alone or in combination might be of clinical utility in the prognostic assessment of prostate cancers.

\section{Supplementary information}

Supplementary information accompanies this paper at https://doi.org/10. 1186/s12885-019-6182-3.

Additional file 1: Table S1. Association between protein tyrosine phosphatase non-receptor 12 (PTPN12) staining results and prostate cancer phenotype in ERG fusion negative tumors. Table S2. Association 
between protein tyrosine phosphatase non-receptor 12 (PTPN12) staining results and prostate cancer phenotype in ERG fusion positive tumors. Table S3. Multivariate analysis including PTPN12 expression in all cancers, ERG negative and ERG positive cancers. Figure S1. PTPN12 expression (negative vs. strong) and biochemical recurrence in (a) classic Gleason grade (b) < 5\% Gleason 4, (c) 6-10\% Gleason 4, (d) 11-20\% Gleason 4, (e) 21-30\% Gleason 4, (f) 31-49\% Gleason 4, (g) 50-60\% Gleason 4, (h) 61$100 \%$ Gleason 4

\section{Abbreviations}

CHD1: Chromodomain-Helicase-DNA-Binding Protein 1; FISH: Fluorescence in-situ hybridization; FOXP1: Forkhead box protein P1;

IHC: Immunohistochemistry; MAP3K7: Mitogen-Activated Protein Kinase Kinase Kinase 7; PSA: Prostate specific antigen; PTEN: Phosphatase and tensin homolog; PTPN12: Protein phosphatase non-receptor 12; TMA: Tissue microarray; TMPRSS2:ERG: Transmembrane protease, serine 2: ETS-related gene fusion

\section{Acknowledgments}

We thank Julia Schumann, Sünje Seekamp and Inge Brandt for excellent technical assistance.

\section{Authors' contributions}

SW, CS, RS, AHe and GS designed the study, and drafted the manuscript. $\mathrm{HHu}, \mathrm{Jl}, \mathrm{HHe}$, Aha, MG and TS participated in study design. AL, SS, and FB performed $\mathrm{IHC}$ analysis and scoring. CM, DH, MT and TC participated in pathology data analysis. CH, CG and RS performed statistical analysis. CF, SK, $\mathrm{EB}, \mathrm{SM}, \mathrm{PL}$, and $\mathrm{DD}$ participated in data interpretation, and helped to draft the manuscript. All authors read and approved the final manuscript.

\section{Funding}

This work was supported by the Federal Ministry for Education and Research of Germany (BMBF) (grant no. ICGC_II FKZ 101KU1505B) to GS. The funding body had no involvement in the design of the study, collection, analysis, and interpretation of data and in writing the manuscript.

\section{Availability of data and materials}

The data supporting the findings of this study are available from the corresponding author upon reasonable request.

\section{Ethics approval and consent to participate}

The ethics committee of the Ärztekammer Hamburg approved this study (WF-049/09). According to local laws (HmbKHG, \$12a) informed consent was not required for this study.

\section{Consent for publication}

Not applicable.

\section{Competing interests}

The authors declare that they have no competing interests.

\section{Author details}

${ }^{1}$ Institute of Pathology, University Medical Center Hamburg-Eppendorf, Martinistrasse 52, 20246 Hamburg, Germany. ${ }^{2}$ General, Visceral and Thoracic Surgery Department and Clinic, University Medical Center Hamburg-Eppendorf, Martinistrasse 52, 20246 Hamburg, Germany. ${ }^{3}$ Department of Urology, Charité - Universitätsmedizin Berlin, Charitéplatz 1, 10117 Berlin, Germany. ${ }^{4}$ Martini-Clinic, Prostate Cancer Center, University Medical Center Hamburg, Eppendorf, Germany.

Received: 29 April 2019 Accepted: 20 September 2019

Published online: 12 October 2019

\section{References}

1. Bray F, Ferlay J, Soerjomataram I, Siegel RL, Torre LA, Jemal A. Global cancer statistics 2018: GLOBOCAN estimates of incidence and mortality worldwide for 36 cancers in 185 countries. CA Cancer J Clin. 2018;68(6):394-424.

2. Coen JJ, Feldman AS, Smith MR, Zietman AL. Watchful waiting for localized prostate cancer in the PSA era: what have been the triggers for intervention? BJU Int. 2011;107(10):1582-6.
3. Li H, Yang F, Liu C, Xiao P, Xu Y, Liang Z, Liu C, Wang H, Wang W, Zheng W, et al. Crystal structure and substrate specificity of PTPN12. Cell Rep. 2016; 15(6):1345-58

4. Dong H, Zonta F, Wang S, Song K, He X, He M, Nie Y, Li S. Structure and Molecular Dynamics Simulations of Protein Tyrosine Phosphatase NonReceptor 12 Provide Insights into the Catalytic Mechanism of the Enzyme. Int J Mol Sci. 2018;19(1):60

5. Li J, Davidson D, Martins Souza C, Zhong MC, Wu N, Park M, Muller WJ, Veillette A. Loss of PTPN12 stimulates progression of ErbB2-dependent breast Cancer by enhancing cell survival, migration, and epithelial-toMesenchymal transition. Mol Cell Biol. 2015;35(23):4069-82.

6. Hunter T. Tyrosine phosphorylation: thirty years and counting. Curr Opin Cell Biol. 2009;21(2):140-6.

7. Villa-Moruzzi E. PTPN12 controls PTEN and the AKT signalling to FAK and HER2 in migrating ovarian cancer cells. Mol Cell Biochem. 2013;375(1-2):151-7.

8. Xu Y, Taylor P, Andrade J, Ueberheide B, Shuch B, Glazer PM, Bindra RS, Moran MF, Linehan WM, Neel BG. Pathologic oxidation of PTPN12 underlies ABL1 phosphorylation in hereditary Leiomyomatosis and renal cell carcinoma. Cancer Res. 2018;78(23):6539-48.

9. Cong F, Spencer S, Cote JF, Wu Y, Tremblay ML, Lasky LA, Goff SP. Cytoskeletal protein PSTPIP1 directs the PEST-type protein tyrosine phosphatase to the c-Abl kinase to mediate Abl dephosphorylation. Mo Cell. 2000;6(6):1413-23.

10. Luo RZ, Cai PQ, Li M, Fu J, Zhang ZY, Chen JW, Cao Y, Yun JP, Xie D, Cai MY. Decreased expression of PTPN12 correlates with tumor recurrence and poor survival of patients with hepatocellular carcinoma. PLoS One. 2014;9(1): e85592.

11. Zhangyuan G, Yin Y, Zhang W, Yu W, Jin K, Wang F, Huang R, Shen H, Wang $X$, Sun B. Prognostic value of Phosphotyrosine phosphatases in hepatocellular carcinoma. Cell Physiol Biochem. 2018;46(6):2335-46.

12. Piao $Y R$, Jin ZH. Protein tyrosine phosphatase nonreceptor type 12 suppresses the proliferation of renal cell carcinoma by inhibiting the activity of the PI3K/mTOR pathway. J BUON. 2015;20(5):1258-66.

13. Piao $Y$, Liu $X$, Lin Z, Jin Z, Jin X, Yuan K, Wu W. Decreased expression of protein tyrosine phosphatase non-receptor type 12 is involved in the proliferation and recurrence of bladder transitional cell carcinoma. Oncol Lett. 2015;10(3):1620-6.

14. Cao X, Li Y, Luo RZ, He LR, Yang J, Zeng MS, Wen ZS. Tyrosine-protein phosphatase nonreceptor type 12 is a novel prognostic biomarker for esophageal squamous cell carcinoma. Ann Thorac Surg. 2012;93(5):1674-80.

15. Su Z, Tian H, Song HQ, Zhang R, Deng AM, Liu HW. PTPN12 inhibits oral squamous epithelial carcinoma cell proliferation and invasion and can be used as a prognostic marker. Med Oncol. 2013;30(3):618.

16. Zhang XK, Xu M, Chen JW, Zhou F, Ling YH, Zhu CM, Yun JP, Cai MY, Luo $R Z$. The prognostic significance of tyrosine-protein phosphatase nonreceptor type 12 expression in nasopharyngeal carcinoma. Tumour Biol. 2015;36(7):5201-8

17. Lin Q, Wang H, Lin X, Zhang W, Huang S, Zheng Y. PTPN12 affects nasopharyngeal carcinoma cell proliferation and migration through regulating EGFR. Cancer Biother Radiopharm. 2018;33(2):60-4.

18. Cao X, Chen YZ, Luo RZ, Zhang L, Zhang SL, Zeng J, Jiang YC, Han YJ, Wen ZS. Tyrosine-protein phosphatase non-receptor type 12 expression is a good prognostic factor in resectable non-small cell lung cancer. Oncotarget 2015;6(13):11704-13.

19. Nair A, Chung HC, Sun T, Tyagi S, Dobrolecki LE, Dominguez-Vidana R, Kurley SJ, Orellana M, Renwick A, Henke DM, et al. Combinatorial inhibition of PTPN12-regulated receptors leads to a broadly effective therapeutic strategy in triple-negative breast cancer. Nat Med. 2018;24(4):505-11.

20. Sahu SN, Nunez S, Bai G, Gupta A. Interaction of Pyk2 and PTP-PEST with leupaxin in prostate cancer cells. Am. J. Physiol. Cell Physiol. 2007; 292(6):C2288-96.

21. Sauter G, Steurer S, Clauditz TS, Krech T, Wittmer C, Lutz F, Lennartz M, Janssen T, Hakimi N, Simon R, et al. Clinical utility of quantitative Gleason grading in prostate biopsies and prostatectomy specimens. Eur Urol. 2016; 69(4):592-8

22. Kononen J, Bubendorf L, Kallioniemi A, Barlund M, Schraml P, Leighton S, Torhorst J, Mihatsch MJ, Sauter G, Kallioniemi OP. Tissue microarrays for high-throughput molecular profiling of tumor specimens. Nat Med. 1998; 4(7):844-7.

23. Tennstedt $P$, Koster $P$, Bruchmann A, Mirlacher M, Haese A, Steuber T, Sauter $G$, Huland H, Graefen M, Schlomm T, et al. The impact of the number of 
cores on tissue microarray studies investigating prostate cancer biomarkers. Int J Oncol. 2012;40(1):261-8.

24. Minner S, Jessen B, Stiedenroth L, Burandt E, Kollermann J, Mirlacher M, Erbersdobler A, Eichelberg C, Fisch M, Brummendorf TH, et al. Low level HER2 overexpression is associated with rapid tumor cell proliferation and poor prognosis in prostate cancer. Clin Cancer Res. 2010;16(5):1553-60.

25. Minner S, Enodien M, Sirma H, Luebke AM, Krohn A, Mayer PS, Simon R, Tennstedt P, Muller J, Scholz L, et al. ERG status is unrelated to PSA recurrence in radically operated prostate cancer in the absence of antihormonal therapy. Clin Cancer Res. 2011;17(18):5878-88.

26. Minner S, Wittmer C, Graefen M, Salomon G, Steuber T, Haese A, Huland H, Bokemeyer C, Yekebas E, Dierlamm J, et al. High level PSMA expression is associated with early PSA recurrence in surgically treated prostate cancer. Prostate. 2011;71(3):281-8.

27. Burkhardt L, Fuchs S, Krohn A, Masser S, Mader M, Kluth M, Bachmann F, Huland $\mathrm{H}$, Steuber T, Graefen M, et al. CHD1 is a 5 q21 tumor suppressor required for ERG rearrangement in prostate cancer. Cancer Res. 2013;73(9): 2795-805.

28. Kluth M, Hesse J, Heinl A, Krohn A, Steurer S, Sirma H, Simon R, Mayer PS, Schumacher U, Grupp K, et al. Genomic deletion of MAP3K7 at 6q12-22 is associated with early PSA recurrence in prostate cancer and absence of TMPRSS2:ERG fusions. Mod Pathol. 2013;26(7):975-83.

29. Krohn A, Diedler T, Burkhardt L, Mayer PS, De Silva C, Meyer-Kornblum M, Kotschau D, Tennstedt P, Huang J, Gerhauser C, et al. Genomic deletion of PTEN is associated with tumor progression and early PSA recurrence in ERG fusion-positive and fusion-negative prostate cancer. Am J Pathol. 2012; 181(2):401-12

30. Krohn A, Seidel A, Burkhardt L, Bachmann F, Mader M, Grupp K, Eichenauer T, Becker A, Adam M, Graefen M, et al. Recurrent deletion of 3 p13 targets multiple tumour suppressor genes and defines a distinct subgroup of aggressive ERG fusion-positive prostate cancers. J Pathol. 2013;231(1):130-41.

31. Kluth M, Scherzai S, Buschek F, Fraune C, Moller K, Hoflmayer D, Minner S, Gobel C, Moller-Koop C, Hinsch A, et al. 13q deletion is linked to an adverse phenotype and poor prognosis in prostate cancer. Genes Chromosomes Cancer. 2018;57(10):504-12.

32. Kluth M, Graunke M, Moller-Koop C, Hube-Magg C, Minner S, Michl U, Graefen M, Huland $H_{\text {, Pompe }}$, Jacobsen $F$, et al. Deletion of $18 \mathrm{q}$ is a strong and independent prognostic feature in prostate cancer. Oncotarget. 2016;7(52):86339-49.

33. Kluth M, Amschler NN, Galal R, Moller-Koop C, Barrow P, Tsourlakis MC, Jacobsen F, Hinsch A, Wittmer C, Steurer S, et al. Deletion of $8 p$ is an independent prognostic parameter in prostate cancer. Oncotarget. 2017; 8(1):379-92.

34. Kluth M, Ahrary R, Hube-Magg C, Ahmed M, Volta H, Schwemin C, Steurer S, Wittmer C, Wilczak W, Burandt E, et al. Genomic deletion of chromosome $12 p$ is an independent prognostic marker in prostate cancer. Oncotarget. 2015;6(29):27966-79.

35. Weischenfeldt J, Simon R, Feuerbach L, Schlangen K, Weichenhan D, Minner S, Wuttig D, Warnatz HJ, Stehr H, Rausch T, et al. Integrative genomic analyses reveal an androgen-driven somatic alteration landscape in earlyonset prostate cancer. Cancer Cell. 2013;23(2):159-70.

36. Kluth M, Jung S, Habib O, Eshagzaiy M, Heinl A, Amschler N, Masser S, Mader M, Runte F, Barow $P$, et al. Deletion lengthening at chromosomes $6 q$ and $16 \mathrm{q}$ targets multiple tumor suppressor genes and is associated with an increasingly poor prognosis in prostate cancer. Oncotarget. 2017;8(65): 108923-35.

37. Kluth M, Harasimowicz S, Burkhardt L, Grupp K, Krohn A, Prien K, Gjoni J, Hass T, Galal R, Graefen M, et al. Clinical significance of different types of p53 gene alteration in surgically treated prostate cancer. Int J Cancer. 2014; 135(6):1369-80.

38. Uhlen M, Zhang C, Lee S, Sjostedt E, Fagerberg L, Bidkhori G, Benfeitas R, Arif M, Liu Z, Edfors F et al. A pathology atlas of the human cancer transcriptome. Science. 2017;357(6352):eaan 2507.

39. Uhlen M, Oksvold P, Fagerberg L, Lundberg E, Jonasson K, Forsberg M, Zwahlen M, Kampf C, Wester K, Hober S, et al. Towards a knowledge-based human protein atlas. Nat Biotechnol. 2010;28(12):1248-50.

40. Epstein Jl, Feng Z, Trock BJ, Pierorazio PM. Upgrading and downgrading of prostate cancer from biopsy to radical prostatectomy: incidence and predictive factors using the modified Gleason grading system and factoring in tertiary grades. Eur Urol. 2012;61(5):1019-24.
41. Lu DW, El-Mofty SK, Wang HL. Expression of p16, Rb, and p53 proteins in squamous cell carcinomas of the anorectal region harboring human papillomavirus DNA. Mod Pathol. 2003;16(7):692-9.

42. Leong WF, Chau JF, Li B. p53 deficiency leads to compensatory upregulation of p16INK4a. Mol Cancer Res. 2009;7(3):354-60.

43. Hu L, Guo M, He Z, Thornton J, McDaniel LS, Hughson MD. Human papillomavirus genotyping and p16INK4a expression in cervical intraepithelial neoplasia of adolescents. Mod Pathol. 2005;18(2):267-73.

44. laconis L, Hyjek E, Ellenson LH, Pirog EC. p16 and Ki-67 immunostaining in atypical immature squamous metaplasia of the uterine cervix: correlation with human papillomavirus detection. Arch Pathol Lab Med. 2007;131(9):1343-9.

45. Xunyi Y, Zhentao Y, Dandan J, Funian L. Clinicopathological significance of PTPN12 expression in human breast cancer. Braz J Med Biol Res. 2012; 45(12):1334-40.

46. Lee HE, Han N, Kim MA, Lee HS, Yang HK, Lee BL, Kim WH. DNA damage response-related proteins in gastric cancer: ATM, Chk2 and p53 expression and their prognostic value. Pathobiology. 2014;81(1):25-35.

47. Jiang $H$, Wang B, Zhang F, Qian Y, Chuang CC, Ying M, Wang Y, Zuo L. The Expression and Clinical Outcome of pCHK2-Thr68 and pCDC25C-Ser216 in Breast Cancer. Int J Mol Sci. 2016;17(11):1803.

48. Davidson B, Bjornerem M, Holth A, Hellesylt E, Hetland Falkenthal TE, Florenes VA. Expression, activation and clinical relevance of CHK1 and CHK2 in metastatic high-grade serous carcinoma. Gynecol Oncol. 2018; 150(1):136-42.

49. Abdel-Fatah TM, Arora A, Alsubhi N, Agarwal D, Moseley PM, Perry C, Doherty R, Chan SY, Green AR, Rakha E, et al. Clinicopathological significance of ATM-Chk2 expression in sporadic breast cancers: a comprehensive analysis in large cohorts. Neoplasia. 2014;16(11):982-91.

50. Burdelski C, Dieckmann T, Heumann A, Hube-Magg C, Kluth M, Beyer B, Steuber T, Pompe R, Graefen M, Simon R, et al. p16 upregulation is linked to poor prognosis in ERG negative prostate cancer. Tumour Biol. 2016;37(9):12655-63.

51. Steurer S, Mayer PS, Adam M, Krohn A, Koop C, Ospina-Klinck D, Tehrani AA, Simon R, Tennstedt P, Graefen M, et al. TMPRSS2-ERG fusions are strongly linked to young patient age in low-grade prostate cancer. Eur Urol. 2014; 66(6):978-81.

52. Fu W, Bubendorf L, Willi N, Moch H, Mihatsch MJ, Sauter G, Gasser TC. Genetic changes in clinically organ-confined prostate cancer by comparative genomic hybridization. Urology. 2000;56(5):880-5.

53. Bubendorf L, Sauter G, Moch H, Schmid HP, Gasser TC, Jordan P, Mihatsch MJ. Ki67 labelling index: an independent predictor of progression in prostate cancer treated by radical prostatectomy. J Pathol. 1996;178(4):437-41.

54. Sun T, Aceto N, Meerbrey KL, Kessler JD, Zhou C, Migliaccio I, Nguyen DX, Pavlova NN, Botero M, Huang J, et al. Activation of multiple protooncogenic tyrosine kinases in breast cancer via loss of the PTPN12 phosphatase. Cell. 2011;144(5):703-18.

55. Brase JC, Johannes M, Mannsperger H, Falth M, Metzger J, Kacprzyk LA, Andrasiuk T, Gade S, Meister M, Sirma H, et al. TMPRSS2-ERG -specific transcriptional modulation is associated with prostate cancer biomarkers and TGF-beta signaling. BMC Cancer. 2011;11:507.

56. Burdelski C, Bujupi E, Tsourlakis MC, Hube-Magg C, Kluth M, Melling N, Lebok P, Minner S, Koop C, Graefen M, et al. Loss of SOX9 expression is associated with PSA recurrence in ERG-positive and PTEN deleted prostate cancers. PLoS One. 2015;10(6):e0128525.

57. Burdelski C, Menan D, Tsourlakis MC, Kluth M, Hube-Magg C, Melling N, Minner S, Koop C, Graefen M, Heinzer H, et al. The prognostic value of SUMO1/Sentrin specific peptidase 1 (SENP1) in prostate cancer is limited to ERG-fusion positive tumors lacking PTEN deletion. BMC Cancer. 2015;15:538.

58. Muller J, Ehlers A, Burkhardt L, Sirma H, Steuber T, Graefen M, Sauter G, Minner S, Simon R, Schlomm T, et al. Loss of pSer2448-mTOR expression is linked to adverse prognosis and tumor progression in ERG-fusion-positive cancers. Int J Cancer. 2013;132(6):1333-40.

59. Tsourlakis MC, Eleftheriadou A, Stender A, Weigand P, Grupp K, Hube-Magg C, Kluth M, Schroeder C, Steurer S, Hinsch A, et al. FOXA1 expression is a strong independent predictor of early PSA recurrence in ERG negative prostate cancers treated by radical prostatectomy. Carcinogenesis. 2017; 38(12):1180-7.

60. Grupp K, Jedrzejewska K, Tsourlakis MC, Koop C, Wilczak W, Adam M, Quaas A, Sauter G, Simon R, Izbicki JR, et al. High mitochondria content 
is associated with prostate cancer disease progression. Mol Cancer. 2013;12(1):145.

61. Stumm L, Burkhardt L, Steurer S, Simon R, Adam M, Becker A, Sauter G, Minner S, Schlomm T, Sirma $H$, et al. Strong expression of the neuronal transcription factor FOXP2 is linked to an increased risk of early PSA recurrence in ERG fusion-negative cancers. J Clin Pathol. 2013;66(7):563-8.

62. Kluth M, Al Kilani Z, Ozden C, Hussein K, Frogh S, Moller-Koop C, Burandt E, Steurer $S$, Buscheck F, Jacobsen F, et al. 5 q21 deletion is often heterogeneous in prostate cancer. Genes Chromosomes Cancer. 2019;58(8): 509-15.

63. Badour K, Zhang J, Shi F, Leng Y, Collins M, Siminovitch KA. Fyn and PTPPEST-mediated regulation of Wiskott-Aldrich syndrome protein (WASp) tyrosine phosphorylation is required for coupling T cell antigen receptor engagement to WASp effector function and T cell activation. J Exp Med. 2004;199(1):99-112.

64. Schrank BR, Aparicio T, Li Y, Chang W, Chait BT, Gundersen GG, Gottesman ME, Gautier J. Nuclear ARP2/3 drives DNA break clustering for homologydirected repair. Nature. 2018;559(7712):61-6.

65. Lyons PD, Dunty JM, Schaefer EM, Schaller MD. Inhibition of the catalytic activity of cell adhesion kinase beta by protein-tyrosine phosphatase-PESTmediated dephosphorylation. J Biol Chem. 2001;276(26):24422-31.

66. Tang K, Constanzo JD, Venkateswaran N, Melegari M, Ilcheva M, Morales JC, Skoulidis F, Heymach JV, Boothman DA, Scaglioni PP. Focal adhesion kinase regulates the DNA damage response and its inhibition Radiosensitizes mutant KRAS lung Cancer. Clin Cancer Res. 2016;22(23):5851-63.

67. Rhee I, Davidson D, Souza CM, Vacher J, Veillette A. Macrophage fusion is controlled by the cytoplasmic protein tyrosine phosphatase PTP-PEST/ PTPN12. Mol Cell Biol. 2013;33(12):2458-69.

68. Zheng Y, Yang W, Xia Y, Hawke D, Liu DX, Lu Z. Ras-induced and extracellular signal-regulated kinase 1 and 2 phosphorylation-dependent isomerization of protein tyrosine phosphatase (PTP)-PEST by PIN1 promotes FAK dephosphorylation by PTP-PEST. Mol Cell Biol. 2011;31(21):4258-69.

69. Davidson D, Shi X, Zhong MC, Rhee I, Veillette A. The phosphatase PTP-PEST promotes secondary $T$ cell responses by dephosphorylating the protein tyrosine kinase Pyk2. Immunity. 2010;33(2):167-80.

70. Espejo R, Rengifo-Cam W, Schaller MD, Evers BM, Sastry SK. PTP-PEST controls motility, adherens junction assembly, and rho GTPase activity in colon cancer cells. Am J Physiol Cell Physiol. 2010;299(2):C454-63.

71. Veillette A, Rhee I, Souza CM, Davidson D. PEST family phosphatases in immunity, autoimmunity, and autoinflammatory disorders. Immunol Rev. 2009;228(1):312-24.

72. Davidson D, Veillette A. PTP-PEST, a scaffold protein tyrosine phosphatase, negatively regulates lymphocyte activation by targeting a unique set of substrates. EMBO J. 2001;20(13):3414-26.

73. Badour K, Zhang J, Siminovitch KA. Involvement of the Wiskott-Aldrich syndrome protein and other actin regulatory adaptors in $\mathrm{T}$ cell activation. Semin Immunol. 2004;16(6):395-407.

74. Spencer S, Dowbenko D, Cheng J, Li W, Brush J, Utzig S, Simanis V, Lasky LA. PSTPIP: a tyrosine phosphorylated cleavage furrow-associated protein that is a substrate for a PEST tyrosine phosphatase. J Cell Biol. 1997;138(4):845-60.

75. Fonar Y, Frank D. FAK and WNT signaling: the meeting of two pathways in cancer and development. Anti Cancer Agents Med Chem. 2011;11(7):600-6.

76. Wu L, Zhao JC, Kim J, Jin HJ, Wang CY, Yu J. ERG is a critical regulator of Wnt/LEF1 signaling in prostate cancer. Cancer Res. 2013;73(19):6068-79.

77. Singh RV, Agashe SR, Gosavi AV, Sulhyan KR. Interobserver reproducibility of Gleason grading of prostatic adenocarcinoma among general pathologists. Indian J Cancer. 2011;48(4):488-95.

78. Iczkowski KA, Lucia MS. Current perspectives on Gleason grading of prostate cancer. Curr Urol Rep. 2011;12(3):216-22.

\section{Publisher's Note}

Springer Nature remains neutral with regard to jurisdictional claims in published maps and institutional affiliations.

Ready to submit your research? Choose BMC and benefit from:

- fast, convenient online submission

- thorough peer review by experienced researchers in your field

- rapid publication on acceptance

- support for research data, including large and complex data types

- gold Open Access which fosters wider collaboration and increased citations

- maximum visibility for your research: over $100 \mathrm{M}$ website views per year

At BMC, research is always in progress.

Learn more biomedcentral.com/submissions 